\begin{tabular}{|l|l|l||}
\hline \multicolumn{2}{|c|}{ PublisherInfo } \\
\hline \hline PublisherName & $:$ & BioMed Central \\
\hline \hline PublisherLocation & $:$ & London \\
\hline \hline PublisherImprintName & $:$ & BioMed Central \\
\hline \hline
\end{tabular}

\title{
Plant pathogen genome
}

\begin{tabular}{|l|c|l||}
\hline \multicolumn{2}{|c|}{ ArticleInfo } \\
\hline \hline ArticleID & $:$ & 4389 \\
\hline \hline ArticleDOI & $:$ & $10.1186 /$ gb-spotlight-20020131-01 \\
\hline \hline ArticleCitationID & $:$ & spotlight-20020131-01 \\
\hline \hline ArticleSequenceNumber & $:$ & 55 \\
\hline \hline ArticleCategory & $:$ & Research news \\
\hline ArticleFirstPage & $:$ & 1 \\
\hline \hline ArticleLastPage & $:$ & 2 \\
\hline \hline & & RegistrationDate : 2002-1-31 \\
\hline ArticleHistory & $:$ & OnlineDate \\
\hline \hline ArticleCopyright & $:$ & BioMed Central Ltd2002-1-31 \\
\hline \hline ArticleGrants & $:$ & \\
\hline \hline ArticleContext & $:$ & 130593311 \\
\hline \hline
\end{tabular}




\section{Jonathan B Weitzman}

Email: jonathanweitzman@hotmail.com

In the January 31 Nature, Salanoubat et al. report the complete genome sequence of the soil-borne plant pathogen Ralstonia solanacearum (Nature 2002, 415:497-502). The French research team sequenced the genome of the $R$. solanacearum GMI1000 strain, which is a pathogen of Arabidopsis thaliana, to gain insights into pathogenicity and host-pathogen interactions. The R. solanacearumgenome is composed of two circular molecules of 3.7 and $2.1 \mathrm{Mb}$, encoding over five thousand predicted proteins. The larger replicon ('the chromosome') encodes all the basic mechanisms required for bacterial survival, while the smaller replicon ('the megaplasmid') is genetically dispensable. The megaplasmid may be involved in fitness and adaptation, and it harbours all the hrp genes required to cause disease. Salanoubat et al.found new genes linked to pathogenicity, or encoding hydrolytic enzymes, toxins, attachment factors and proteins required for hormone induction or resistance to oxidative stress. They identified a large number of genes encoding the type III secretion system, and the effector proteins that it delivers, which are essential for pathogenicity; they also found evidence suggesting that some of these pathogenicity genes may have been acquired by horizontal gene transfer.

\section{References}

1. Nature, [http://www.nature.com]

2. Common and contrasting themes of plant and animal diseases.

3. R. solanacearum genome, [http://sequence.toulouse.inra.fr/R.solanacearum.html] 